\title{
INFLUENCE OF PSYCHO-SOCIO-ECONOMIC FACTORS, PARENTING STYLE, AND SIBLING RIVALRY, ON MENTAL AND EMOTIONAL DEVELOPMENT OF PRESCHOOL CHILDREN IN SIDOARJO DISTRICT
}

\author{
Rahma Fauziyah ${ }^{1)}$, Harsono Salimo²), Bhisma Murti ${ }^{1)}$ \\ 1)Masters Program in Public Health, Sebelas Maret University \\ ${ }^{2)}$ Department of Pediatrics, Dr. Moewardi Hospital, Surakarta
}

\begin{abstract}
Background: Preschool development is an influential basic stage for further development. Parents and siblings have an important role for a child's development. Parenting may be the best tool for the development of complete and integrated childhood personality. This study aimed to examine the influence of psycho-socio-economic factors, parenting style, and sibling rivalry, on mental and emotional development of preschool children.

Subjects and Method: This was an analytic observational study using cross sectional design. The study was conducted at 4 Community Health Centers, Sidoarjo District, East Java, from March to May 2017. A sample of 120 preschool children were selected for this study by multistage random sampling. The dependent variable was mental and emotional development. The independent variables were maternal education, family income, number of children, belief of child value, parenting style, and sibling rivalry. The data were collected by a set of questionnaire. Path analysis was employed for data analysis.

Results: Mental and emotional development was directly affected by authoritative parenting style $(\mathrm{b}=4.81 ; 95 \% \mathrm{CI} 3.05$ to $6.56 ; \mathrm{p}=<0.001)$ and sibling rivalry $(b=2.45 ; 95 \% \mathrm{CI}=0.92$ to $3.99 ; \mathrm{p}=0.002)$. Authoritative parenting style was positively affected by maternal education $\geq$ senior high school ( $b=2.14 ; 95 \%$ CI 0.03 to $4.24 ; p=0.046$ ), family income $\geq$ minimum regional wage $(\mathrm{b}=1.41 ; 95 \% \mathrm{CI} 0.07$ to $2.75 ; \mathrm{p}=0.038)$ and positive belief of child value $(b=1.34 ; 95 \%$ CI $<0.01$ to $2.68 ; p=0.049)$. Family income was affected by maternal education $\geq$ senior high school $(b=2.84 ; 95 \%$ CI 1.85 to 3.83; $\mathrm{p}=<0.001)$. Sibling rivalry was affected by number of children $\geq 2(\mathrm{~b}=$ $1.85 ; 95 \%$ CI 1.06 to $2.65 ; \mathrm{p}=<0.001)$. Number of children $\geq 2$ was affected by positive belief of child value ( $b=3.77 ; 95 \% \mathrm{CI} 2.27$ to $5.27 ; \mathrm{p}=<0.001)$.

Conclusion: Mental and emotional development is directly affected by parenting style and sibling rivalry. It is indirectly affected by maternal education, family income, belief of child value, and number of children.
\end{abstract}

Keywords: parenting style, sibling rivalry, mental and emotional development, preschool children

Correspondence: Rahma Fauziyah. Masters Program in Public Health, Sebelas Maret University, Jl. Ir. Sutami 36 A, Surakarta 57126, Central Java, Indonesia. Email: rahma2niez@yahoo.com. Mobile: +6281230701591 